\title{
Pharmacy Students' Experiences, Preferences and Perceptions on Online Assessment
}

\author{
Ezlina Usir, Mohamad Nadzlen Ahamad \\ 1'Department of Pharmacy Practice, Faculty of Pharmacy, Universiti Teknologi MARA, Kampus Puncak Alam, 42300 Bandar Puncak \\ Alam, Selangor.
}

\begin{abstract}
Introduction: As online education becomes more popular so does online assessment. Objectives: The aims of this study are to determine the students' experiences, preferences and perceptions of the online assessment. Methodology: The instrument consists of a selfanswered 45 items questionnaire. The online assessments refer to quizzes and tests from any of the courses listed in the academic plan and conducted using the i-learn platform. Data was collected from 248 students of Bachelor of Pharmacy (Honours) in Universiti Teknologi MARA (UiTM) from all level of study according to the quantity in the stratified sample. The respondents were given 10 minutes to answer the questionnaire before it was collected. The data were analyzed using SPSS version 21.0. Results: Majority of the students $(65.3 \%)$ had attempted more than five online assessments, access it from home $(64.1 \%)$ and use a notebook (84.3\%) with a Google Chrome browser $65.7 \%)$. Slightly over a third (40.7\%) experienced technical problem while attempting the assessment and a third $(30.1 \%)$ of the problems were resolved within a day. Majority of the students rated their experience of online assessment ranging from 5-8 on a scale of 1-10 with speed of the internet connection as the most important factor to be considered. Most of the students gave a 'neutral' and 'agree' statement in terms of perceptions and tend to answer 'agree' and 'strongly agree' towards the statement on the preferences of online assessment. Conclusion: The neutral perceptions showed that there is room for improvement in conducting online assessment such as user-friendly interface, providing an accurate assessment of their knowledge and a challenging assessment for the course.
\end{abstract}

Key words: Online assessment, Pharmacy students, Preferences, Perceptions, Experiences.

\section{INTRODUCTION}

Online assessment is assessment techniques using technology, which includes exam, quiz, survey and test. However, each type of assessment has its own delivery issues that need to be addressed to accomplish its purpose. ${ }^{1}$

More than three quarter $(77 \%)$ of academic leaders rated that learning outcomes in e-learning as the same or superior to face to face instruction. ${ }^{2}$ The advantages of online assessment includes acquiring feedback instantly which improve learning, easy submission of assessment, reduce marking time for educators, ability to assess the students' growth and learning quality, adaptive test- ing where questions are tailored to student proficiency, adoption of a more flexible question format and a potential to present a more complex scenario through interactive resources. ${ }^{3,4}$

The disadvantages includes limitation of objective questions in assessing students' work, assessment tend to be knowledge base rather than measuring the learning progress, ${ }^{3}$ difficulty in identifying the person taking the assessment are the genuine students and possibility of student finding the solution through the Web during the assessment and make the assessment meaningless. ${ }^{5}$ These issues can be overcome
Submission Date: 14-11-2016; Revision Date: 03-01-2017; Accepted Date: 15-02-2017

DOI: 10.5530/ijper.51.3.63 Correspondence: EZLINA USIR,

Department of Pharmacy Practice, Faculty of Pharmacy, Universiti Teknolog MARA, Kampus Puncak Alam, 42300 Bandar Puncak Alam, Selangor. Tel: 603-32584618/60122987556

Fax: 03-32584602; E-mail: ezlin365@puncakalam.uitm.edu.my

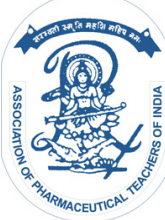

www.ijper.org 
by implementing appropriate strategies; dishonesty by using a log-in system, detecting resources from the web by making it an open book assessment and minimizing student collaboration with each other when taking the assessment by setting a reasonable time limit. ${ }^{6}$

In a study to measure the learners' perceptions toward the web-based distance learning activities, overall students reported that the assignments given promote their learning. ${ }^{7}$ In a survey exploring the future trends of online education in the United States documented that online testing and exam tools would be mostly used for the evaluation form in the future. ${ }^{8}$ In Australia, a study comparing the perception of online assessment between the first-years university students, the perception was influenced by the design of the online assessment, the nature of the subject and frequency of assessments. The paper also concluded online assessment can improve the learning process. ${ }^{9}$

In Malaysia, institutions of higher education have implemented online assessment in their learning and teaching. In UiTM, e-Learning Center (i-LEC) was established since December 2005 and was responsible to provide and implement the services to create the environment where lecturers can provide Web-based learning contents and online learning activities. ${ }^{10}$ Academics' instructors can upload the course materials online, create an online discussion to enhance the student learning progress and assist in the depth of learning. The demand on classrooms can be reduce; the online materials can be provided cheaper and distributed swifter to the students. Examples of the online activities are tutorials, announcement, discussion and online assessment. In UiTM, ' $i$-learn' is used as a platform to systematize the e-learning. ${ }^{10}$ However, data on student's view on the implementation of this technique with regards to their experiences, preferences and perceptions are limited.

The objectives of the study were to determine the students' experiences, preferences and perceptions towards online assessment. In this study, the assessments were limited to quizzes and tests.

\section{METHODOLOGY}

This study was a cross sectional study involving undergraduates from Faculty of Pharmacy, Universiti Teknologi MARA, Puncak Alam Campus. This population consists of 695 students. The total sample size that was used for this survey is calculated using Cochran's sample size formula for categorical data.

$\mathrm{n}^{0}=(\mathrm{t})^{2} *(\mathrm{p})(\mathrm{q})$

$(\mathrm{d})^{2}$

$\mathrm{n}^{0}=(1.96)^{2} *(0.5)(0.5)=384$

$(0.05)^{2}$

Where $\mathrm{t}=$ value for selected alpha level of 0.025 in each tail $=1.96$

$(p)(q)=$ estimate of variance $=0.25$

$\mathrm{d}=$ acceptable margin of error for proportion being estimated $=0.05$

Therefore for a population of 695 , the required sample size is 384 . However, since this exceeds $5 \%$ of the population $(0.05$ x $695=35)$, Cochran's $(1977)$ correction formula was used to calculate the final sample size as follows:

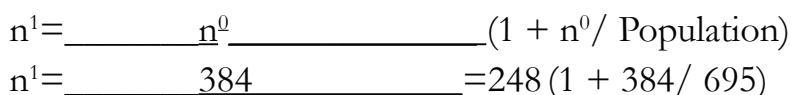

Where population size $=695$

$\mathrm{n}^{0}=$ required return sample size according to Cochran's formula $=384$

$\mathrm{n}^{1}=$ required return sample size because sample $>5 \%$ of population

Using Cochran's formula above, the final sample size used for this study was $248 .{ }^{11}$ Proportionate stratified random sampling technique was later applied to obtain the sample size for each stratum as in Table 1.

The inclusion criteria for the subjects include undergraduates from Faculty of Pharmacy at UiTM Puncak Alam campus, have experienced attempting the online assessment at least once from any courses listed in their academic plan and the assessment were conducted using the $i$-learn platform. Students under the students exchange programme, students that have no experience

\begin{tabular}{|c|c|c|c|}
\hline \multicolumn{3}{|c|}{ Table 1: Number of respondents in each semester, (N=248) } \\
\hline Semester & $\begin{array}{c}\text { Number of students } \\
\text { (Strata size) }\end{array}$ & $\begin{array}{c}\text { Calculation } \\
\text { (Strata size/Total size) } \\
\text { x Total sample size }\end{array}$ & $\begin{array}{c}\text { Stratified } \\
\text { sample size }\end{array}$ \\
\hline 2 & 206 & $(206 / 695) \times 248$ & 74 \\
\hline 4 & 160 & $(160 / 695) \times 248$ & 57 \\
\hline 6 & 168 & $(168 / 695) \times 248$ & 60 \\
\hline 8 & 161 & $(161 / 695) \times 248$ & 57 \\
\hline $\begin{array}{c}\text { Total students } \\
\text { (Population) }\end{array}$ & 695 & Total sample size & 248 \\
\hline
\end{tabular}


in the online assessment and students that have been selected in the pilot study were excluded in this research. The instrument consists of four parts questionnaire with 45 items. The questionnaire was adapted from Smorfitt et al. ${ }^{9}$ The first part consists of demographic information ( 7 items), the second part was on the experience of the respondents undertaking the online assessment (9 items), the third part was on perception of the students towards the assessment (18 items) and the last part was on the preferences of the respondents on online assessment (11 items). Response options were varied depending on the types of questions that were asked. They included multiple choice answers, close ended questions and 5 points Likert-scale response.

The research proposal was presented to the faculty and approval was obtained to conduct the study. Pilot study was conducted and followed by reliability test of the questions provided in the questionnaire. Reliability was tested using Cronbach Alpha and, as a result, some of the questions were negatively worded and the score for the questions were reversed for analysis. The results from the pilot study were excluded in the final analysis. Questionnaires were distributed to the volunteered respondents according to the quantity in the stratified sample. The respondents were given 5 to 10 minutes to answer the questionnaires before it was collected. Data was analyzed by using SPSS 21.0 program.

\section{RESULTS}

The total numbers of respondents were 248 which majority consisted of female $(82.7 \%)$, with a Cumulative Grade Point Average (CGPA) of 3.00 - 3.49(62.1\%), matriculation as entry qualification $(62.5 \%)$ and staying in a rented house $(86.3 \%)$. Two-third of the respondents $(65.3 \%)$, had completed the assessment online more than five times, completed it at home (64.1\%) using a laptop (84.3\%) and accessing it via Google Chrome $(65.7 \%)$. Slightly more than half $(52.0 \%)$ remembered when they need to attempt the online assessment and over half of the respondents (59.3\%) never had any problems completing their online assessment. However, more than a third $(40.7 \%)$ of the students had problems at least once while completing their assessment. Among those who had problems $(30.7 \%)$ reported that it took within one day to resolve their problems and almost a third $(29.7 \%)$ managed to solve it within a few hours -Table 2.

On the important considerations when attempting the online assessment, the speed of the internet connection $(85.5 \%)$ was chosen as the most important aspect fol-

\begin{tabular}{|c|c|c|}
\hline \multicolumn{2}{|c|}{ Demographic characteristics } & Frequency \\
\hline \multirow[t]{2}{*}{ Gender } & Female & $205(82.7)$ \\
\hline & Male & $43(17.3)$ \\
\hline \multirow[t]{4}{*}{ Current CGPA } & $3.50-4.00$ & $30(12.1)$ \\
\hline & $3.00-3.49$ & $154(62.1)$ \\
\hline & $2.20-2.99$ & $62(25.0)$ \\
\hline & $2.00-2.19$ & $2(0.8)$ \\
\hline \multirow[t]{3}{*}{ Entry qualification: } & Matriculation & $155(62.5)$ \\
\hline & Diploma & $65(26.2)$ \\
\hline & Foundation & $28(11.3)$ \\
\hline \multirow[t]{3}{*}{ Current residence } & Rental house & $214(86.3)$ \\
\hline & College & $31(12.5)$ \\
\hline & Family house & $3(1.2)$ \\
\hline \multirow{6}{*}{$\begin{array}{l}\text { Number of times taken } \\
\text { the online assessment }\end{array}$} & 2 & $8(3.2)$ \\
\hline & 3 & $4(1.6)$ \\
\hline & 4 & $5(2.0)$ \\
\hline & 5 & $6(2.4)$ \\
\hline & More than 5 & $162(65.3)$ \\
\hline & Can't remember & $63(25.4)$ \\
\hline \multirow{4}{*}{$\begin{array}{l}\text { Frequently used } \\
\text { location when } \\
\text { attempting online } \\
\text { assessment }\end{array}$} & Home & $159(64.1)$ \\
\hline & College & $40(16.1)$ \\
\hline & Computer lab & $40(16.1)$ \\
\hline & Faculty & $9(3.6)$ \\
\hline \multirow{4}{*}{$\begin{array}{l}\text { Frequently used } \\
\text { device to perform } \\
\text { online assessment }\end{array}$} & Laptop & $209(84.3)$ \\
\hline & Desktop & $29(11.7)$ \\
\hline & Tablet & $6(2.4)$ \\
\hline & Smartphone & $4(1.6)$ \\
\hline \multirow{4}{*}{$\begin{array}{l}\text { Primary browser used } \\
\text { to perform online } \\
\text { assessment }\end{array}$} & Google Chrome & $163(65.7)$ \\
\hline & Internet Explorer & $60(24.2)$ \\
\hline & Mozilla Firefox & $21(8.5)$ \\
\hline & Safari & $4(1.6)$ \\
\hline \multirow{3}{*}{$\begin{array}{l}\text { Reminder to attempt } \\
\text { online assessment }\end{array}$} & Remember on my own & $129(52.0)$ \\
\hline & Reminder from friends & $98(39.5)$ \\
\hline & $\begin{array}{c}\text { Didn't notice until last } \\
\text { minute }\end{array}$ & $21(8.5)$ \\
\hline \multirow{2}{*}{$\begin{array}{l}\text { Experienced problem } \\
\text { during online } \\
\text { assessment }\end{array}$} & No & $147(59.3)$ \\
\hline & Yes & $101(40.7)$ \\
\hline \multirow{5}{*}{$\begin{array}{l}\text { Time to resolve with } \\
\text { administration }(\mathrm{N}=101)\end{array}$} & Within a few hours & $30(29.7)$ \\
\hline & Within one day & $31(30.7)$ \\
\hline & 2 days & $17(16.8)$ \\
\hline & 3 days & $6(5.9)$ \\
\hline & About a week & $17(16.8)$ \\
\hline
\end{tabular}


lowed by type of browser (32.3\%) type of internet and device used $(28.2 \%)$ and a private area $(4.8 \%)$.

Almost half of the respondents (44.7\%) agreed that the implementation of the online assessment is compatible with the course objective. However, despite agreeing with the previous statement, nearly half $(46.0 \%)$ indicated that they neither agree nor disagree on online assessment provides an accurate assessment of their knowledge on the course content- Table 3. Neverthe- less, majority agreed $(70.6 \%)$ that the online assessment contributed a higher percentage of marks among other continuous assessment marks.

Two-third $(64.1 \%)$ agreed that it was easy to perform the assessment although it involves utilization of a computer. Furthermore, almost half of the respondents $(46.4 \%)$ agreed that they did not have problem to access the internet to perform the online assessment. Onethird $(36.3 \%)$ of the respondents disagreed that their

\begin{tabular}{|c|c|c|c|c|c|c|c|c|}
\hline No & Question & $\begin{array}{l}\text { Strongly } \\
\text { Disagree } \\
\text { N (\%) }\end{array}$ & $\begin{array}{l}\text { Disagree } \\
\mathbf{N}(\%)\end{array}$ & $\begin{array}{l}\text { Neutral N } \\
(\%)\end{array}$ & $\begin{array}{l}\text { Agree } N \\
(\%)\end{array}$ & $\begin{array}{l}\text { Strongly } \\
\text { Agree N } \\
(\%)\end{array}$ & Mean & Median \\
\hline 1. & $\begin{array}{l}\text { From my experience, the implementation of } \\
\text { the online assessment is compatible with the } \\
\text { course objective. }\end{array}$ & $7(2.8)$ & $24(9.7)$ & $106(42.7)$ & $103(41.5)$ & $8(3.2)$ & 3.33 & 3 \\
\hline 2. & $\begin{array}{l}\text { Online assessment provides an accurate } \\
\text { assessment of my knowledge on the course } \\
\text { content. }\end{array}$ & $9(3.6)$ & $40(16.1)$ & $114(46.0)$ & $75(30.2)$ & $10(4.0)$ & 3.15 & 3 \\
\hline 3. & $\begin{array}{l}\text { Online assessment can contribute a higher } \\
\text { percentage of marks for my continuous } \\
\text { assessment marks. }\end{array}$ & $4(1.6)$ & $16(6.5)$ & $53(21.4)$ & $115(46.4)$ & $60(24.2)$ & 3.85 & 4 \\
\hline 4. & $\begin{array}{l}\text { I found it is easy to perform the assessment } \\
\text { using a computer. }\end{array}$ & $3(1.2)$ & $23(9.3)$ & $63(25.4)$ & $125(50.4)$ & $34(13.7)$ & 3.66 & 4 \\
\hline 5. & $\begin{array}{l}\text { I usually do not have problem to access the } \\
\text { internet during the online assessment. }\end{array}$ & $6(2.4)$ & 49 (19.8) & 78 (31.5) & 99 (39.9) & $16(6.5)$ & 3.28 & 3 \\
\hline 6. & $\begin{array}{l}\text { My focus is easily distracted when attempting } \\
\text { the assessment using PCs/Laptop/devices. }\end{array}$ & $17(6.9)$ & $73(29.4)$ & $80(32.3)$ & $69(27.8)$ & $9(3.6)$ & 2.92 & 3 \\
\hline 7. & $\begin{array}{l}\text { I do not feel forced to do the online } \\
\text { assessment. }\end{array}$ & $22(8.9)$ & 94 (37.9) & $100(40.3)$ & $28(11.3)$ & $4(1.6)$ & 2.59 & 3 \\
\hline 8. & $\begin{array}{c}\text { I can easily google for a solution while doing } \\
\text { an online assessment. }\end{array}$ & 45 (18.1) & $103(41.5)$ & 77 (31.0) & $16(6.5)$ & $7(2.8)$ & 2.34 & 2 \\
\hline 9. & $\begin{array}{l}\text { It is easier to cheat/copy while attempting the } \\
\text { online assessment compared to conventional } \\
\text { assessment. }\end{array}$ & 50 (20.2) & 89 (35.9) & 89 (35.9) & $18(7.3)$ & $2(0.8)$ & 2.33 & 2 \\
\hline 10. & $\begin{array}{l}\text { It is easier for my friend to copy my answer } \\
\text { while attempting the online assessment } \\
\text { compared to conventional assessment. }\end{array}$ & $37(14.9)$ & $106(42.7)$ & $81(32.7)$ & 22 (8.9) & $2(0.8)$ & 2.38 & 2 \\
\hline 11. & $\begin{array}{l}\text { I personally agree with the implementation of } \\
\text { the online assessment with the course I take. }\end{array}$ & $2(0.8)$ & $21(8.5)$ & $110(44.4)$ & $88(35.5)$ & 27 (10.9) & 3.47 & 3 \\
\hline 12. & $\begin{array}{l}\text { I think other students are agreeing with the } \\
\text { implementation of the online assessment. }\end{array}$ & 0 & $15(6.0)$ & $115(46.4)$ & $87(35.1)$ & $31(12.5)$ & 3.54 & 3 \\
\hline 13. & $\begin{array}{l}\text { Online assessment does not affect my ability } \\
\text { to answer the questions. }\end{array}$ & $4(1.6)$ & $44(17.7)$ & $119(48.0)$ & $73(29.4)$ & $8(3.2)$ & 3.15 & 3 \\
\hline 14. & $\begin{array}{c}\text { An online environment makes me feel more } \\
\text { comfortable participating in the course } \\
\text { assessment. }\end{array}$ & $6(2.4)$ & $23(9.3)$ & $113(45.6)$ & $92(37.1)$ & $14(5.6)$ & 3.34 & 3 \\
\hline 15. & $\begin{array}{c}\text { The interface of the online assessment is user } \\
\text { friendly. }\end{array}$ & $1(0.4)$ & $29(11.7)$ & $111(44.8)$ & 99 (39.9) & $8(3.2)$ & 3.34 & 3 \\
\hline 16. & $\begin{array}{l}\text { I do not feel challenged by the coursework } \\
\text { that need me to use online assessment. }\end{array}$ & $10(4.0)$ & $53(21.4)$ & $110(44.4)$ & $69(27.8)$ & $6(2.4)$ & 3.03 & 3 \\
\hline 17. & $\begin{array}{l}\text { I was able to do the online assessment } \\
\text { without difficulty. }\end{array}$ & $2(0.8)$ & $43(17.3)$ & $103(41.5)$ & $91(36.7)$ & $9(3.6)$ & 3.25 & 3 \\
\hline 18. & $\begin{array}{l}\text { I feel stressful and anxious when attempting } \\
\text { the assessment online. }\end{array}$ & $14(5.6)$ & $71(28.6)$ & $92(37.1)$ & $61(24.6)$ & $10(4.0)$ & 2.93 & 3 \\
\hline
\end{tabular}


focus are easily distracted when attempting the assessment using computer. However, almost half (46.8\%) disagree to the statement that they do not feel forced to perform the online assessment.

Majority of them $(59.6 \%)$ disagreed that it was easy to find or google for the solution while taking the online assessment. However, a significantly higher percentage of male students agreed that it was easier to google for a solution while attempting online assessment compared to female students $(\mathrm{p}=0.014)$. More than a half $(56.1 \%)$ disagree that it is easy to copy while performing the online assessment and a similar percentage (57.6\%) disagreed that it is easier for their friends to copy their answer while attempting the online assessment. The students however agreed with the implementation of online assessment (46.4\%) and perceived that their friends had similar opinion (47.6\%).

The students were uncertain on assessment affecting ability to answer questions (48.0\%), feeling comfortable participating in the assessment $(45.6 \%)$, user friendliness of the interface $(44.8 \%)$, not feeling challenged by the assessment (44.4\%), able to do online assessment without difficulty (41.5\%) and feeling stressful and anxious when attempting online assessment (37.1\%).

Response showed that almost half of the respondents $(45.2 \%)$ favoured online environment as a course assessment and preferred to have more online assessment in their courses (40.8\%). Male students significantly favoured online assessment compared to female students $(\mathrm{p}=0.029)$. However, a similar percentage $(42.7 \%)$ expressed that they had uncertain preference on the statement 'the online assessment is similar to the conventional assessment'- Table 4.

When performing the online assessment, there were strong preferences in multiple choice questions rather than essays (88.3\%), acquiring their result immediately (87.5\%), using 'open book' concept (83.9\%), discovering the correct answer for their self-learning (83.9\%), flexibility in time and location $(74.6 \%)$ and having a system with a marker or indicator in order for them to indicate the questions that they have problem with or have not been answered (70.5\%).

\begin{tabular}{|c|c|c|c|c|c|c|c|c|}
\hline No & Question & $\begin{array}{c}\text { Strongly } \\
\text { Disagree } \\
\text { N (\%) }\end{array}$ & $\begin{array}{c}\text { Disagree } \mathbf{N} \\
(\%)\end{array}$ & $\begin{array}{c}\text { Neutral N } \\
(\%)\end{array}$ & $\begin{array}{l}\text { Agree } \\
\mathrm{N}(\%)\end{array}$ & $\begin{array}{c}\text { Strongly } \\
\text { Agree N (\%) }\end{array}$ & Mean & Median \\
\hline 1. & $\begin{array}{l}\text { It is favorable to have online } \\
\text { environment in the course } \\
\text { assessment. }\end{array}$ & $2(0.8)$ & $25(10.1)$ & $\begin{array}{c}109 \\
(44.0)\end{array}$ & $\begin{array}{c}94 \\
(37.9)\end{array}$ & $18(7.3)$ & 3.41 & 3 \\
\hline 2. & $\begin{array}{l}\text { I have similar preferences to online } \\
\text { and conventional assessment. }\end{array}$ & $4(1.6)$ & $37(14.9)$ & $\begin{array}{c}106 \\
(42.7)\end{array}$ & $\begin{array}{c}79 \\
(31.9)\end{array}$ & $22(8.9)$ & 3.31 & 3 \\
\hline 3. & $\begin{array}{l}\text { I prefer multiple choice questions } \\
\text { rather than essay questions. }\end{array}$ & 0 & $3(1.2)$ & $26(10.5)$ & $\begin{array}{c}96 \\
(38.7)\end{array}$ & $123(49.6)$ & 4.37 & 4 \\
\hline 4. & $\begin{array}{l}\text { I prefer to know the results directly } \\
\text { after the assessment. }\end{array}$ & 0 & $4(1.6)$ & $27(10.9)$ & $\begin{array}{c}124 \\
(50.0)\end{array}$ & $93(37.5)$ & 4.23 & 4 \\
\hline 5. & $\begin{array}{l}\text { 'Open book' concept for online } \\
\text { assessment is more favorable. }\end{array}$ & 0 & $5(2.0)$ & $35(14.1)$ & $\begin{array}{c}122 \\
(49.2)\end{array}$ & $86(34.7)$ & 4.17 & 4 \\
\hline 6. & $\begin{array}{l}\text { At least, correct answer is given for } \\
\text { my self-learning. }\end{array}$ & 0 & $2(0.8)$ & $38(15.3)$ & $\begin{array}{c}123 \\
(49.6)\end{array}$ & 85 (34.3) & 4.17 & 4 \\
\hline 7. & $\begin{array}{l}\text { I prefer more flexibility in time } \\
\text { and location for attempting the } \\
\text { assessment. }\end{array}$ & 0 & $6(2.4)$ & $57(23.0)$ & $\begin{array}{c}125 \\
(50.4)\end{array}$ & $60(24.2)$ & 3.96 & 4 \\
\hline 8. & $\begin{array}{l}\text { I do need some marker/indicator } \\
\text { in order for me to indicate which } \\
\text { questions that I have not answered } \\
\text { or have problem with. }\end{array}$ & $3(1.2)$ & $12(4.8)$ & $58(23.4)$ & $\begin{array}{c}107 \\
(43.1)\end{array}$ & $68(27.4)$ & 3.91 & 4 \\
\hline 9. & $\begin{array}{l}\text { Essay questions should be } \\
\text { eliminated in online assessment. }\end{array}$ & $7(2.8)$ & $16(6.5)$ & $62(25.0)$ & $\begin{array}{c}74 \\
(29.8)\end{array}$ & 89 (35.9) & 3.90 & 4 \\
\hline 10. & $\begin{array}{l}\text { I prefer to have multiple questions in } \\
\text { one page rather than one page for } \\
\text { one question. }\end{array}$ & $4(1.6)$ & $14(5.6)$ & $70(28.2)$ & $\begin{array}{c}102 \\
(41.1)\end{array}$ & $58(23.4)$ & 3.79 & 4 \\
\hline 11. & $\begin{array}{l}\text { It would be good if there is more } \\
\text { online assessment in my courses. }\end{array}$ & $9(3.6)$ & $40(16.1)$ & $98(39.5)$ & $\begin{array}{c}85 \\
(34.3)\end{array}$ & $16(6.5)$ & 3.24 & 3 \\
\hline
\end{tabular}




\section{DISCUSSION}

Majority of the respondents perceived that the implementation of online assessment is compatible with the course objective but were undecided on provision of accurate assessment of their knowledge of the course objective which differs from previous study where computerized assessments provided accurate assessment in measuring student learning. ${ }^{9}$ Majority agreed that it was easy to performed computerized assessment and disagreed that their focus were easily distracted when using computer which was consistent with previous study and might be due to the integration between the internet and computers that make up the system and results in easier process. ${ }^{9}, 12$

In this study, respondents were uncertain on the user friendliness of the interface of the online assessment contrary to another study where positive perception was reported. ${ }^{12}$ This could be due to overall configuration and design of the online assessment. The study also found that over a third the students were uncertain on feeling stressful and anxious when attempting online assessment differing to the previous study where the impact of the students' stress and anxiety is less when performing online assessment compared to conventional way. This could be due to the nature of the subject itself. ${ }^{\text {? }}$

In this study, majority disagree that it is easy to copy while performing the online assessment and that it is easier for their friends to copy their answer while attempting the online assessment. This finding was consistent in one study ${ }^{9}$ but in contrast in others. ${ }^{12,13}$ This study showed that almost half favoured online environment as a course assessment and preferred to have more online assessment in their courses but was uncertain whether the online assessment is similar to the conventional assessment. Previous study reported that conventional assessment was favoured over online assessment ${ }^{14}$ while others showed students preferred the online compared to the conventional assessment., 12 Continuous e-assessment has also been shown to increased student engagement and learning leading to improvement in quality of student experience. ${ }^{15}$

The respondents in this study preferred to have multiple questions in one page rather than one page for each question. However, the study from Ozden et al. indicates that $70 \%$ of their respondent felt better with page by page questions. This difference may be because of the students' personal preferences. ${ }^{9}$ Respondents also reported strong preferences on the flexibility in time and location, acquiring results immediately and discovering the correct answer for their self-learning, consistent with previous study. ${ }^{9}$ This might motivate the students as well as improve the students self-learning.

This survey however, is limited to the respondents from one university and the result may not represent pharmacy student in other universities that were exposed to online assessment with different software, facilities and interfaces. The survey also relied on self reporting method and with Likert scale, there were tendency to respond towards the middle of the scale.

\section{CONCLUSION}

The results from the study showed that majority of the pharmacy students strongly agreed with most of the preferences statements but their perception were inconclusive. These results can be useful in constructing and improving the online assessment system for future uses.

\section{CONFLICT OF INTEREST}

None

\section{REFERENCES}

1. Hricko M, Howell SL. Online Assessment and Measurement: Case Studies from Higher Education, K-12 and Corporate: Idea Group Inc 2006. https://doi. org/10.4018/978-1-59140-720-1 ; PMCid:PMC1440794.

2. Allen IE, Seaman J. Changing course: Ten years of tracking online education in the United States. Babson Survey Research Group 2013;43:47.

3. McKimm J, Jollie C, Cantillon P. ABC of learning and teaching: Web based learning.BMJ 2003;326(7394):870-3. https://doi.org/10.1136/ bmj.326.7394.870 ; PMid:12702625 PMCid:PMC1125774.

4. Robles M, Braathen S. Online assessment techniques. Delta Pi Epsil J 2002;44:39-49.

5. Turau V, Fahrenholtz D, Venzke M. Online Assessment for University Admission: Goals, Problems, and Experience. 8th International CAA Conference; Germany 2005.

6. Olt MR. Ethics and distance education: Startegies for minimizing academic dishonesty in online assessment. Online Journal of Distance Learning administration [Internet] 2002; 5(3). Available from: http://www.westga. edu/ distance/ojdla/fall53/olt53.html.

7. Koohang A, Durante A. Learners' Perceptions toward the Web-based Distance Learning Activities/Assignments Portion of an Undergraduate Hybrid Instructional Model. J Inform Technol Edu 2003;2:105-13.

8. Kim K-J, Bonk CJ. The Future of Online Teaching and Learning in Higher Education: The Survey Says. Educause Quarterly 2006;29(4):22-30.

9. Smorfitt D, Wybrow R, Taylor P. Students' perceptions of on-line assessment: Financial and educational implications. In Frielick S, Buissink-Smith N, Wyse P, Billot J, Hallas J, Whitehead E, editors. Research and Development in Higher Education: The Place of Learning and Teaching. Auckland, New Zealand, 1 - 4 July 2013. 36 p. 444 - 54.

10. Adora E, Posiah MI, Siti Rahayu AA, Hajar MN, Hasrul J, Azlan AA. e-Learning For Universiti Teknologi MARA Malaysia (UiTM): Campus wide implementation and accomplishments. Procedia- Soc Behavioral Sciences 2012;67:26-35. https://doi.org/10.1016/j.sbspro.2012.11.304.

11. Bartlett II JE, Kotrlik JW, Higgins CC. Organizational Research: Determining Appropriate Sample Size in Survey Research. Inf Technol Learn Perfom J. 2001;19(1):43-50.

12. Özden MY, Ertürk I, Sanli R. Students' Perceptions of Online Assessment: A Case Study. J Distance Educ. 2004;19(2):77-92 
13. King AE, Guyette R, Piotrowski C. Online exams and cheating: An empirical analysis of business students' views. J Educators Online. 2009;6(1):1-11. https://doi.org/10.9743/JEO.2009.1.5.

14. Llamas-Nistal M, Caeiro M, Castro M, Plaza I, Tovar E, editors. Use of LMS functionalities in engineering education. 41st ASEE/IEEE Frontiers in Education Conference (FIE 2011) 2011.
15. Holmes N. Student perceptions of their learning and engagement in response to the use of a continuous e-assessment in an undergraduate module. Assess Eval High Educ 2015;40(1):1-14. https://doi.org/10.1080/0 2602938.2014.881978.

\section{About Authors}

Ezlina Usir: Lecturer in Pharmacy Practice Department, Faculty of Pharmacy, Universiti Teknologi MARA. Research interests include community pharmacy related areas, pharmacy education and drug information.

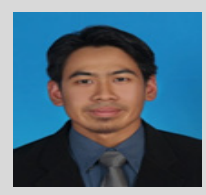

\section{SUMMARY}

- Flexibility in time and location, acquiring results immediately and discovering the correct answer for their self-learning were the preferred criteria for online assessment.

- There is room for improvement in providing a userfriendly interface and a challenging and accurate assessment of their knowledge in developing an online assessment.

Mohamad Nadzlen Ahamad: Pharmacist in Manufacturing Division, Pharmaniaga. He was a student in Faculty of Pharmacy, Universiti Teknologi MARA.

Cite this article: Usir E, Ahamad MN. Pharmacy Students' Experiences, Preferences and Perceptions on Online Assessment. Indian J of Pharmaceutical Education and Research. 2017;51(3):373-9. 